\title{
Capping it off
}

\author{
H. William Strauss, MD
}

\section{See related article, pp. 753-762}

Atherosclerosis progresses silently for decades before producing sudden catastrophic clinical events. During the late preclinical phase, when there is no end organ damage, there can be major savings in terms of health care costs and a major reduction in morbidity and mortality, if lesions likely to produce a clinical event can be identified and treated. Indirect measures of inflammation, such as C-reactive protein (CRP), are often employed as an indicator of risk for cardiovascular events. ${ }^{1}$ Although CRP is sensitive, it is not very specific. Adding other measurements, such as circulating levels of monocyte/macrophage colony stimulating factor (MCSF) increases the predictive value of the assays to identify patients at risk for major cardiovascular events. ${ }^{2}$ To determine the specific organs at risk, it is necessary to add an imaging procedure to survey the vasculature. Over the past 20 years, criteria to identify atheroma, especially in the carotid arteries, have been developed using multiple modalities, including magnetic resonance imaging, ${ }^{3}$ computed tomography, ${ }^{4}$ intravascular ultrasound, ${ }^{5}$ and radionuclide imaging. ${ }^{6}$ The clinical challenge, however, is not just localizing the disease, but characterizing the lesion. Several radiopharmaceuticals have been designed to localize in atheroma based on specific attributes of the lesion. ${ }^{7,8}$ The distribution of these agents can be readily depicted on combined images of anatomy and pathophysiology with hybrid PET-CT, SPECT-CT, or fusion with magnetic resonance images. ${ }^{9}$

Inflammation is found throughout the life of atheroma. Since macrophages consume exogenous glucose to meet their energy needs, the radiolabeled glucose

From the Nuclear Medicine Service, Department of Radiology, Memorial Sloan Kettering Cancer Center, New York, NY.

Reprint requests: H. William Strauss, MD, Nuclear Medicine Service, Department of Radiology, Memorial Sloan Kettering Cancer Center, New York, NY 10021; straussh@mskcc.org.

J Nucl Cardiol 2009;16:686-8.

1071-3581/\$34.00

Copyright (C) 2009 by the American Society of Nuclear Cardiology. doi:10.1007/s12350-009-9124-7 analog, 2-fluoro-2-deoxy-D-glucose (FDG), has been used to visualize inflammation in the lesions. ${ }^{10} \mathrm{~A}$ high prevalence of vascular FDG uptake was seen ${ }^{11-13}$ especially in patients with elevated biomarkers. Since inflammation is present throughout the life of the lesion, from inception to rupture, and is only extinguished as lesions calcify, ${ }^{14}$ it may not be a suitable marker to identify patients at imminent risk for vascular events. The same can be said for lipoprotein cholesterol, ${ }^{15}$ oxidized lipoprotein cholesterol, ${ }^{16,17}$ or identification of cellular elements such as macrophages and T-cells (see Figure 1). As a result, imaging lipids, inflammation, or cells may be very useful to define the presence and location of lesions, but not as a marker of vulnerability.

A major component of atheroma is the cap, providing the barrier separating the lesion from the flowing blood. In atheroma, vascular smooth muscle cells (VSMC) are stimulated to proliferate (by plateletderived growth factor, fibroblast growth factor, and transforming growth factor $\beta$ ) and migrate ${ }^{18}$ (from their normal location in the media, through the internal elastic lamina into the intima ${ }^{19}$ ). The chemokines and cytokines causing VSMC migration and stimulation are produced by injured endothelial cells, tissue macrophages, and lymphocytes in the lesion. The factors causing migration of the VSMCs also stimulate both the proteolysis and production of collagen, elastin, and proteoglycans that form the cap of the atheroma. The maturity of the collagen and thickness of the cap are the result of a balance between production of proteoglycans by VSMC and their catabolism by a series of matrix metalloproteinases (MMPs). MMPs are zinc dependent endopeptidases capable of degrading extracellular matrix protein, cleaving cell surface receptors, and inducing apoptosis (through production of fas ligand). ${ }^{20}$ This family of 23 proteinases, discovered 47 years ago as the agents responsible for tail resorption during frog metamorphosis, ${ }^{21}$ can be produced by all cells in the wall ${ }^{22}$ of the blood vessel. MMPs play a dual role in atheroma, they allow controlled remodeling of the vessel and migration of VSMC to stabilize the lesion on the one hand, and in excess cause thinning of the cap and contribute to plaque rupture. ${ }^{23}$ Activated macrophages appear to be the major source of MMPs in atheroma. ${ }^{24}$

Macrophages, programmed to ingest and digest cholesterol in the plaque, gorge themselves on lipoprotein-cholesterol complexes and toxic oxidized low 


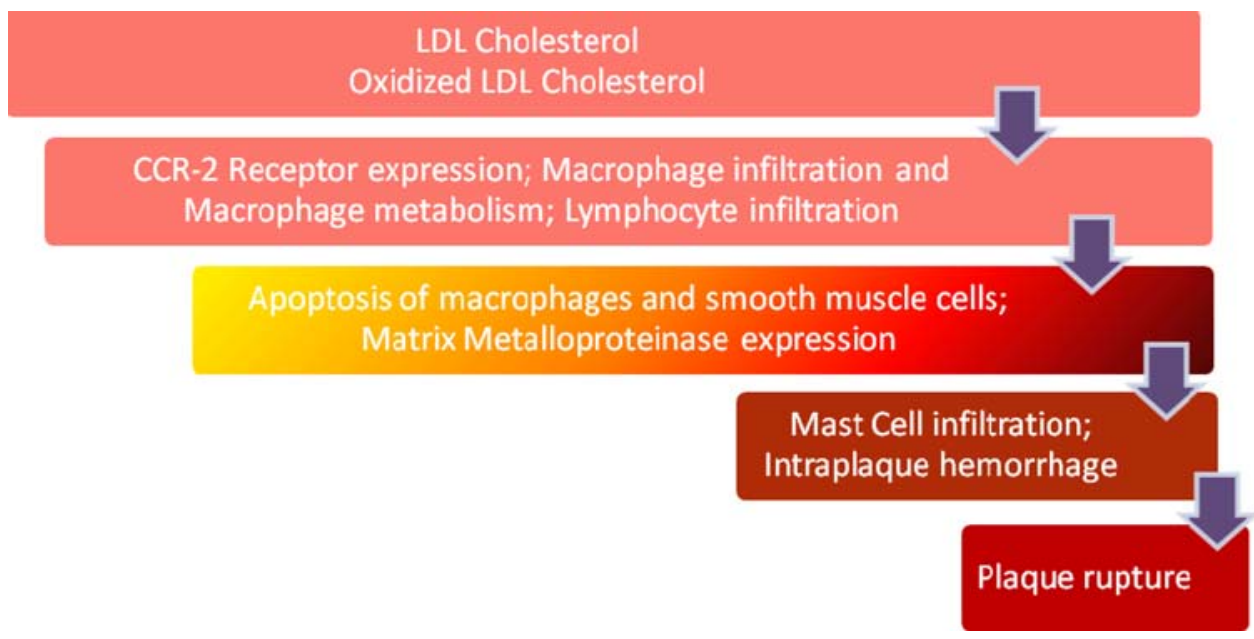

Figure 1. Major steps in the progression of atheroma from inception of the fatty streak (top row) to plaque rupture (bottom row).

density lipoprotein-cholesterol. ${ }^{25}$ These cells become stressed, causing them to release MMPs and undergo apoptosis. Both apoptosis and the release of MMPs appear to identify a later stage in the evolution of the lesion than pan atheroma markers, such as inflammation or lipoprotein-cholesterol or oxidized lipoprotein cholesterol. Based on their important role in the evolution of vulnerable atheroma, several groups have developed imaging approaches to MMPs. ${ }^{26-28}$

In this issue of the Journal, Haider et al. ${ }^{29}$ describe a very elegant series of experiments documenting the distribution of a radiolabeled MMP inhibitor and radiolabeled annexin- $\mathrm{V}$, a marker of apoptosis in the cholesterol fed rabbit/injured aorta model of atheroma. The investigators observed a high level of apoptosis and MMP expression (particularly MMP-9) in the untreated animals with late stage atheroma. Eliminating cholesterol from the diet or maintaining the diet and treating with fluvastatin decreased apoptosis and MMP expression in the lesions. Figure 2 of the Haider manuscript highlights the relationship of these two markers. While the distributions are similar, they are not identical, suggesting that each marker is contributing different information about the lesion.

In addition to demonstrating the geographic relationship of apoptosis and expression of MMP, the investigators went one step further, to demonstrate the mechanism involved in MMP expression. A monocytic leukemia cell line, THP-1 cells, was transfected to overexpress caspase-1. Caspase-1 is a member of the cysteine protease family of enzymes associated with apoptosis. Caspase-1 activation promotes secretion of proinflammatory cytokines. ${ }^{30}$ Caspase production occurs when cells are stressed. If the cells are severely stressed, caspase levels are high enough to induce the apoptotic cascade, with externalization of the membrane phospholipid phospatidylserine, initiation of DNAases, and orderly packaging of cellular elements into apoptosomes for phagocytosis. Lower levels of stress cause lower concentrations of caspase, leading to externalization of phosphatidylserine, but not the initiation of the full catastrophic proteolysis associated the cell destruct sequence. The investigators observed a 25fold increase in the production MMP-9 in the transfected cells. This observation documents the relationship of this initiator of apoptosis to the production of MMP. In addition the investigators also demonstrated increased MMP-9 production when THP-1 cells were incubated with oxysterol, cholesterol-5 $\beta$, and 7-ketocholesterol.

The combination of imaging apoptosis and MMP production is a major step toward the goal of imaging vulnerable plaque. It is likely that additional steps will be required to achieve the goal. One approach may include specific cellular imaging of mast cells (Unfortunately, there are no methods currently available to selectively label these cells.). The presence of mast cells correlates with the vulnerable lesion. Activated mast cells release cytokines, growth factors, and proteolytic enzymes such as tryptase and chymase. Mast cells colocalize in the rupture prone shoulder region of the plaque, and at perivascular sites associated with intraplaque hemorrhage. ${ }^{31}$ As a result of these observations, it is likely that selective imaging of activated mast cells, especially when combined with imaging of apoptosis and MMP expression, will provide a specific indicator of advanced, rupture prone lesions. 


\section{References}

1. Gaziano JM, Manson JE, Ridker PM. Primary and secondary prevention of coronary heart disease. Chapter 42. In: Zipes DP, Libby P, Bonow RO, Braunwald E, editors. Braunwalds heart disease. 7th ed. Philadelphia, PA: Elsevier Saunders; 2005. p. $1057-84$.

2. Ikonomidis I, Stamatelopoulos K, Lekakis J, Vamvakou GD, Kremastinos DT. Inflammatory and non-invasive vascular markers: The multimarker approach for risk stratification in coronary artery disease. Atherosclerosis 2008;199(1):3-11.

3. Fabiano S, Mancino S, Stefanini M, Chiocchi M, Mauriello A, Spagnoli LG, et al. High-resolution multicontrast-weighted MR imaging from human carotid endarterectomy specimens to assess carotid plaque components. Eur Radiol 2008;18(12):2912-21.

4. Das M, Braunschweig T, Mühlenbruch G, Mahnken AH, Krings $\mathrm{T}$, Langer $\mathrm{S}$, et al. Carotid plaque analysis: Comparison of dualsource computed tomography (CT) findings, histopathological correlation. Eur J Vasc Endovasc Surg 2009;38(1):14-9.

5. Kim SH, Hong MK, Park DW, Lee SW, Kim YH, Lee CW, et al. Impact of plaque characteristics analyzed by intravascular ultrasound on long-term clinical outcomes. Am J Cardiol 2009; 103(9):1221-6.

6. Saraste A, Nekolla SG, Schwaiger M. Cardiovascular molecular imaging: An overview. Cardiovasc Res; 2009 Jun 24. [Epub ahead of print] PMID: 19553359.

7. Langer HF, Haubner R, Pichler BJ, Gawaz M. Radionuclide imaging-A molecular key to the atherosclerotic plaque. J Am Coll Cardiol 2008;52:1-12.

8. Kelly KA, Nahrendorf M, Yu AM, Reynolds F, Weissleder R. In vivo phage display selection yields atherosclerotic plaque targeted peptides for imaging. Mol Imaging Biol 2006;8(4):201-7.

9. Silvera SS, Aidi HE, Rudd JH, Mani V, Yang L, Farkouh M, Fuster V, Fayad ZA. Multimodality imaging of atherosclerotic plaque activity and composition using FDG-PET/CT and MRI in carotid and femoral arteries. Atherosclerosis; 2009 Apr 24. [Epub ahead of print] PMID: 19467659.

10. Rudd JHF, Myers KS, Bansilal S, Machac J, Woodward M, Fuster V, Farkouh ME, Fayad ZA. Relationships among regional arterial inflammation, calcification, risk factors and biomarkers-A prospective FDG PET/CT imaging study. Circ Cardiovasc Imaging 2009;2:107-15. doi:10.1161/CIRCIMAGING.108.811752.

11. Tahara N, Kai H, Ishibashi M, Nakaura H, Kaida H, Baba K, et al. Simvastatin attenuates plaque inflammation: Evaluation by fluorodeoxyglucose positron emission tomography. J Am Coll Cardiol 2006;48(9):1825-31.

12. Tahara N, Kai H, Nakaura H, Mizoguchi M, Ishibashi M, Kaida H, et al. The prevalence of inflammation in carotid atherosclerosis: Analysis with fluorodeoxyglucose-positron emission tomography. Eur Heart J 2007;28(18):2243-8.

13. Tang TY, Moustafa RR, Howarth SP, Walsh SR, Boyle JR, Li ZY, et al. Combined PET-FDG and USPIO-enhanced MR imaging in patients with symptomatic moderate carotid artery stenosis. Eur J Vasc Endovasc Surg 2008;36(1):53-5.

14. Dunphy MP, Freiman A, Larson SM, Strauss HW. Association of vascular $18 \mathrm{~F}-\mathrm{FDG}$ uptake with vascular calcification. J Nucl Med 2005;46(8):1278-84.

15. Lees RS, Lees AM, Strauss HW. External imaging of human atherosclerosis. J Nucl Med 1983;24(2):154-6.
16. Ishino S, Mukai T, Kuge Y, Kume N, Ogawa M, Takai N, et al. Targeting of lectinlike oxidized low-density lipoprotein receptor 1 (LOX-1) with 99mTc-labeled anti-LOX-1 antibody: Potential agent for imaging of vulnerable plaque. J Nucl Med 2008; 49(10):1677-85.

17. Li DY, Patel A, Klibanov A, Kramer CM, Beller GA, Glover DK, et al. Molecular imaging of atherosclerotic plaques targeted on oxidized LDL receptor LOX-1 using SPECT/CT and magnetic resonance. J Nucl Med 2009;50:657-8.

18. Schoen FJ. Blood vessels. Chapter 11. In: Kumar V, Abbas AK, and Fausto N, editors. Robbins and Cotran pathologic basis of disease. 7th ed. Philadelphia, PA: Elsevier Saunders; 2005. p. 511-54.

19. Libby P. The vascular biology of atherosclerosis. Chapter 35. In: Zipes DP, Libby P, Bonow RO, and Braunwald E, editors. Braunwalds heart disease. 7th ed. Philadelphia, PA: Elsevier Saunders; 2005. p. 921-37.

20. http://en.wikipedia.org/wiki/Matrix_metalloproteinase.

21. Tallant C, Marrero A, Gomis-Ruth FX. Matrix metalloproteinases. Biochim Biophys; 2009. doi:10.1016/j.bbamcr.2009.04.003.

22. Newby AC. Dual role of matrix metalloproteinases (matrixins) in intimal thickening and atherosclerotic plaque rupture. Phys Rev 2005;85:1-31.

23. Johnson JL. Matrix metalloproteinases: Influence on smooth muscle cells and atherosclerotic plaque stability. Expert Rev Cardiovasc Ther 2007;5:265-82.

24. Newby AC. Metalloproetinase expression in monocytes and macrophages and its relationship to atherosclerotic plaque instability. Aterioscler Throm Vasc Boil 2008;28:2108-14.

25. Li DY, Patel A, Klibanov A, Kramer CM, Beller GA, Glover DK, et al. Molecular imaging of atherosclerotic plaques targeted on oxidized LDL receptor LOX-1 using SPECT/CT and magnetic resonance. J Nucl Med 2009;50:657-8.

26. Zhang J, Nie L, Razavian M, Ahmed M, Dobrucki LW, Asadi A, et al. Molecular imaging of activated matrix metalloproteinases in vascular remodeling. Circulation 2008;118(19):1953-60.

27. Wagner S, Breyholz HJ, Höltke C, Faust A, Schober O, Schäfers $\mathrm{M}$, et al. A new 18F-labelled derivative of the MMP inhibitor CGS 27023A for PET: Radiosynthesis and initial small-animal PET studies. Appl Radiat Isot 2009;67(4):606-10.

28. Ohshima S, Petrov A, Fujimoto S, Zhou J, Azure M, Edwards DS, et al. Molecular imaging of matrix metalloproteinase expression in atherosclerotic plaques of mice deficient in apolipoprotein e or low-density-lipoprotein receptor. J Nucl Med 2009;50(4):612-7.

29. Haider N, Hartung D, Fujimoto S, Petrov A, Kolodgie FD, Virmani R, Oshima S, Liu H, Zhou J, Fujimoto A, Tahara A, Hofstra L, Narula N, Reutelingsperger C, Narula J. Dual molecular imaging for targeting metalloproteinase activity and apoptosis in atherosclerosis: molecular imaging facilitates understanding of pathogenesis. J Nucl Cardiol 2009. doi:10.1007/s12350-0099107-8.

30. Franchi L, Eigenbrod T, Munoz-Planillo R, Nunex G. The inflammasome: A caspase-1 activation platform that regulates immune responses and disease pathogenesis. Nat Immun 2009;10:241-7.

31. Galkina E, Ley K. Immune and inflammatory mechanisms of atherosclerosis. Annu Rev Immunol 2009;27:165-97. 